\title{
Google Forms: An Assessment Tool Accommodating the Generation-Z Students' Learning Needs
}

\author{
Citra Suryanovika
}

\author{
Sekolah Tinggi Bahasa Asing Pontianak, Pontianak \\ (csuryanovika@yahoo.com)
}

Article History: Submitted December $30^{\text {th }}, 2019$; Accepted March $10^{\text {th }}, 2020$; Published March $13^{\text {th }}, 2020$

\begin{abstract}
The study employed qualitative approach because the data were students' responses on Google Forms, and students' midterm score. It was aimed to exploring the use of Google forms in assessing students' knowledge of the materials of Introduction to Linguistics. The materials were given until the sixth meetings in the Odd Semester of 2019/2020 were linguistics, the phonological term, pronunciation of certain words, the morphological formation and construction. Eleven questions on Google forms were in multiple choice, checkbox, multiple choice/checkbox grid, and short answer. The study has found that most of the students in Class A and Class B firstly used Google forms as the assessment tool with duration was set. Google form is useful for the teacher and students because it provides automatic calculation which enables effective and efficient feedback for the students to learn their mistakes. The study also found that auto grading on Google forms only calculates the correct answers which marked in the answer key feature. Thus, it would be suitable for grading questions in multiple choice and multiple choice grid, questions in checkboxes, short answer, and checkbox grid still needs manual grading. After comparing the score of assessment on Google Forms and midterm test, it can be concluded that students' score was improved significantly after the assessment.
\end{abstract}

Keywords: Google Forms, assessment, generation-Z, students' learning needs

Abstrak. Penelitian in imenggunakan pendekatan kualitatif mengingat data yang digunakan adalah respon mahasiswa dari Google Form, dan nilai Ujian Tengah Semester Mahasiswa. Penelitian ini bertujuan untuk mengetahui penggunaan Google form dalam menial pengetahuan mahasiswa akan materi mata kuliah Introduction to Linguistics. Materi-materi yang siberian hinge minggu keenam di Semester Ganjil than ajaran 2019/2020 adalah linguistik, istilah fonologi, pengucapan kata-kata tertentu, pembentukan dan konstruksi morfologis. Sebelas pertanyaan di Google Forms dalam bentuk pilihan ganda, kotak centang, kisi pilihan ganda/kotak centang, dan jawaban singkat. Penelitian ini telah menemukan bahwa sebagian besar mahasiswa Kelas A dan Kelas B baru pertama kali menggunakan Google Forms sebagai alat penilaian dengan durasi yang telah ditetapkan. Pada praktinya, Google Forms berguna bagi dosen dan mahasiswa karena adanya penghitungan otomatis yang memungkinkan umpan balik yang efektif dan efisien kepada mahasiswa untuk mempelajari kekeliruan mereka.Penelitian ini juga menemukan bahwa penilaian otomatis Google Forms hanya menghitung jawaban benar yang ditandai di figure kunci jawaban. Sehingga, penghitungan nilai hanya berlaku pada sol dengan pilihan ganda dan kisi pilihan ganda, penghitungan nilai secara manual masih harus dilakukan pada sol dalam bentuk kotak centang, kisi kotak centang dan jawaban singkat. Setelah membandingkan nilai pada Google Forms dan Ujian Tengah Semester, ditemukan bahwa nilai mahasiswa meningskat cukup signifikan setelah penilaian dengan Google Forms.

Kata kunci: Google Forms, penilaian, generasi-Z, kebutuhan pembelajaran mahasiswa. 


\section{INTRODUCTION}

The advance of technology facilitates teachers to have effective and efficient teaching process. Technology in teaching is not merely on the use of projector or internet as teaching media, some online tools enable teachers or students to be creative in teaching and learning process. Nowadays, teachers cannot resist or even ban the use of smart phone in classroom activities because they are teaching technology-savvy generations which assume that information is on their fingertip. Generally, the conservative teaching approach preferably does not allow the use of smart phone in classroom activity to prevent cheating and plagiarism which likely occurs due to lack of students' academic integrity and teachers' systemic prevention.

It is generally known that accessible source engine may answer all logical and illogical questions, in which the Generation- $Z$ students accustoms to technology may utilise the facilities very well, and it is likely that they are not using conservative way in learning. Thus, it is undeniably that teachers should adjust their teaching method to students' needs, as Jones, Jo, \& Martin (2007) initially claimed that traditional teaching style is no longer compatible with recent condition, and they suggested school to transform the educational system in order to accommodate students' needs.

This study was designed after considering the way to engage with Generation- $Z$ students that obviously have different perspective from the researcher who is millennial. The researcher viewed how Generation-Z students' learning needs and approaches are different, not only that they have different language expression, but also their intimate connection with smart phone. Teaching Generation- $Z$ students, thus, becomes a new challenge for every millennial teacher to adjust teaching approaches and techniques.

\section{The Generation-Z Students' Needs}

Meeting the first-semester students is always pleasure yet challenging for every teacher who should be able to accommodate different needs. Students of Sekolah Tinggi Bahasa Asing/STBA Pontianak divides into two types, they are the students who are freshly graduated from senior high school, and the students who are also workers. The former type can be categorised into Generation-Z students aged 19-24 years old who pursues the degree either because they want to improve their English or they dream of a great future, while the latter is above 20 years old taking afternoon class because they are working in the morning and they pursue the degree for their career advancement.

Understanding students' needs through their generation is important for English teachers, especially when dealing with students who have different level of English language skill. According to Cohen(2016:24), Generation X is people born in the years 1964-1974, Generation Y or the so-called "Millennial" (1976-1995), and Generation Z or "digital natives"/"children of the screen" are born from 1995 onwards. Differently, Mohr \& Mohr(2017:86)compared the year of birth of Gen Y, Gen X and Gen Z. They claimed that Generation X was born in 1965-1980, while Generation Y was in 1981-1994, and Generation $\mathrm{Z}$ was born in 1995-2010. Apart from differences in the year of birth, Generation Z is currently in university student age. Mohr \& Mohr (2017:87) concluded that Generation $\mathrm{Z}$ students are optimistic, and they also like challenges yet unimaginative, easily distracted; thus, they suggested teachers to guide Generation- $Z$ students in doing work cooperatively, and to limit source of information. Hence, in Sekolah Tinggi Bahasa Asing/STBA Pontianak, students in the morning class are Generation-Z students who 
merely come to school for learning, while students in the afternoon class are workers that consist of Generation Y and Generation Z.

Cohen(2016) suggested teachers to cope with technology in educational system and new generation. Fernández-Cruz \& Fernández-Díaz (2016:97) also have the similar perspective, they highlighted their study on examining teachers' ICT skill, and concluded that teachers' digital competence is significant for learning process. Some previous researchers discussed the usage of social media in learning, for example Handayani (2016) who described Instagram for learning four English skills. In addition, Hidayati(2016:56) recommended Indonesian teachers to integrate ICT in classroom activities since the usage may facilitate teaching and learning process.

In other words, teachers should be able to operate any kind of technological device before modifying traditional teaching method. There are many tools which can support be accessed online or offline, and without any charge. Besides, guideline to use the tools is also available which can facilitate the users to explore them for teaching and learning media. The use of technology is resistible in classroom activities in order to accommodate Generation Z students' needs and to adjust to technology-savvy environment. Devi, Gouthami, \& Lakshmi (2019:100) also concluded that social networks in the blended learning method which teachers have to guide and balance students' activities. Referring to Cilliers (2017), Generation $\mathrm{Z}$ or the so-called digital natives because they were born in the era where technology is spreadably used. Cilliers(2017) studied the Generation Z students' learning environment preferences, and she has recommended teachers to arrange creative environment which enables the use of software, hardware, digital and social media.

Teaching Introduction to Linguistics to the first-semester students in Sekolah Tinggi Bahasa Asing/STBA Pontianak is a quite challenging duty because of some reasons. First, the students never heard about Linguistics before, they are unfamiliar with all terms used in the classroom; thus, the teacher should make sure they understand the terms to enable them in analysing. Second, most of the students are high school graduates that accustom to teacher-centred learning; practicing student-centred learning requires more time. Third, students' needs and competences are varied; students with low English skills learn the materials slower than those with high English skills. Fourth, students come from different regions which actually determine their English basic skills since they may start learning English differently; they also have different familial or occupational background. After considering that the students have different needs, the researcher modified the course assessment from conservative discussion to online Google form. The researcher also found that face to face discussion had some weaknesses, particularly regarding students' passive responses toward the given questions; students still had to be appointed, and the process only motivated active students.

\section{Google Forms For Assessing Students' Knowledge}

In order to make sure that students master the given materials, the lecturers should conduct regular evaluation and assessment.Jabbarifar(2009) stated "the purpose of classroom assessment and evaluation is to give students the opportunity to show what they have learned rather than catching them out or to show what they have not learned." In addition, according to Guskey \& Anderman (2013:21), assessment determines students' knowledge, in which students should be able to answer a set of questions of certain subject. 
In addition, Kumara, Brahmana, \& Paik(2019:20)agreed that assessment of students' capability through questions. It was initiated byAalaei, Ahmadi, \& Aalaei (2016:16741675) which explained that evaluating students' competence is a way to motivate them in learning. They also categorised two common questions which can be used for the evaluation and assessment, they are multiple choice and essay question. They defined multiple choice as the objective question leading the test takers to choose the expected answer, it suitably designed for a large number of respondent, and it facilitates the examiner in scoring; while, essay requires thorough assessment because the test takers tend to write their knowledge in their respective style; thus, it is suitable for a small number of respondent.

In assessing and assessing students' knowledge, some previous researchers often referred to Bloom's taxonomy. InDunham, Yapa, \& Yu (2015:3), Bloom's six levels of mastery includes "knowledge (define, duplicate, list, memorize), comprehension (classify, describe, explain, identify), application (apply, demonstrate, employ, illustrate), analysis (analyze, appraise, categorize), synthesis (arrange, compose, construct, create, design), and evaluation (appraise, argue, assess, compare)". They said that "Bloom's taxonomy aims to rank the complexity of a task, measuring depth of mastery, and as such does not correlate exactly with difficulty. For instance, asking a student to repeat the third bullet point on the second slide in the fifth lecture would demand great powers of recall from the student, but no demonstration of higher mastery".

After considering the importance of assessment, the researcher looked for online survey tool which is compatible for the students of STBA Pontianak. Online survey tool is the best option for promoting paperless classroom activities. According to Alkamel \& Chouthaiwale(2018:31-32), two types of ICT are non-web based learning (TV, Radio, Films, Language Lab, Overhead Projector) and web based learning (Youtube, E-mail, Blog, Skype, Mobile Phone, and iPods). Teachers may use ICT in prepraring teaching materials, implementing teaching and learning process, engaging with students, evaluating and assessing students' mastery. Salas-Morera, Arauzo-Azofra, \& García-Hernández, (2012)have examined the use of online quizzes for five years, found that its use improves students' learning performance. Quizzes to evaluate students' knowledge of given material or course, then, can be through the usage of ICT. Haddad \& Kalaani(2014) used Google form to gather students' feedback on course instruction. In the meantime, Kato \& Kambayashi (2016)promoted students' self-regulatory learning through the use of Google forms. Purwati(2019)also promoted autonomous learning through the use of mobile application in learning Syntax. Castro (2018), furthermore, concluded that Google forms are compatible to either novice or expert in using technology.

Compared to another online survey tool, Google form is simple and compatible to be used to the first-semester students. Raju \& Harinarayana(2018)compared Google form with another online survey tool, and they listed many features of Google form which are not available in another online survey tool.

Therefore, the researcher considered to use Google form in assessing students' knowledge of given materials in Introduction to Linguistics class. The assessment aims at assessing students' knowledge and motivating them in learning Introduction to Linguistics. Questions made for the Google form were designed after considering students' learning outputs. 


\section{METHOD}

The study used a qualitative approach to explore the use of Google forms in assessing students' knowledge of Introduction to Linguistics materials. The data were students' responses on Google Forms, and students' midterm score.

To collect the data, the researcher observed, collected students' responses on Google Forms and recorded students' midterm score. In doing the observation, the researcher was a complete participant that totally engaged in students' learning process, this characteristic fitsCreswell(2014). The researcher taught two classes of Introduction to Linguistics subject for the first semester students of STBA Pontianak, both classes had same materials; thus, the researcher used Google forms to both classes. The researcher designed the questionnaire on Google form by considering materials which have been learned by the students before midterm test. The form for Class A consisted of 11 questions, while the form for Class B consisted of 13 questions; however, the study only focused on the eleven questions which the comparison of both class was possible. The students were filling the form using their own phones or laptops within the given duration, they were only allowed to fill it for forty minutes because the researcher set a time. In addition, the researcher also collected the charts on responses, and students' midterm score to compare their score.

In data analysis, the researcher organised the spreadsheet of students' responses to check the grading validity and reliability. The researcher also used the summary of responses to draw conclusion regarding the use of Google forms in assessing students' knowledge. Besides, the average score of midterm test was calculated using common formula. The results and discussion were presented descriptively afterwards.

\section{RESULTS AND DISCUSSION}

Several templates of Google form suit to everyone's preference or need; however, the templates only consists of basic examples (such as the answers require description, short answer, multiple choice and checkboxes). Practically, Google form is simple, the researcher only had to classify the questions according to the learning phase and question difficulty. In using Google Forms, the researcher listed the questions before making the form, and considered the materials which students had learned. The researcher made two different forms designed to two classes as seen in the following figure.

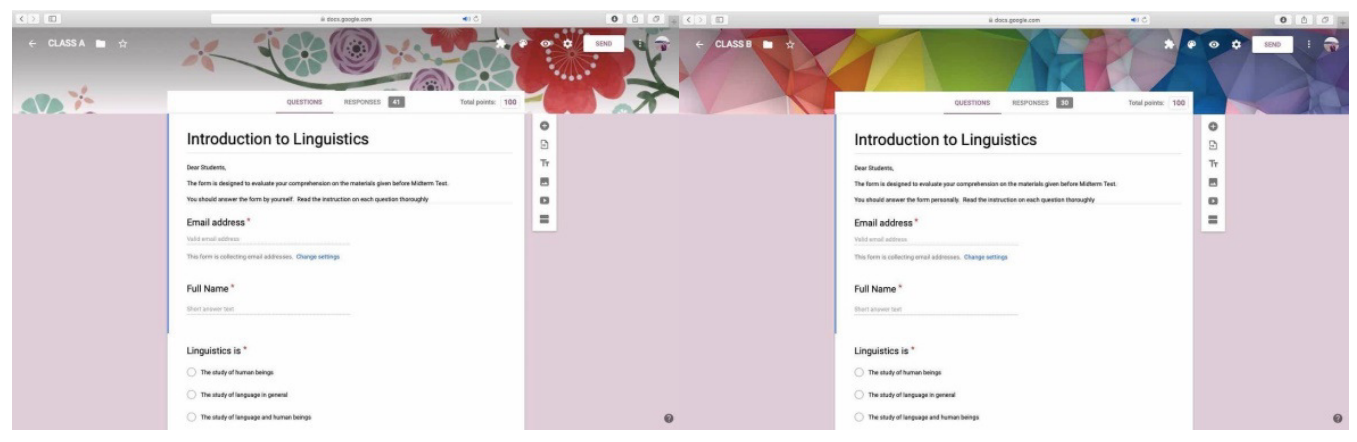

Figure 1 Screenshot of Google Forms for Class A and Class B

Class A had eleven questions, while Class B had thirteen questions because the latter had practiced the syntactical tree diagram. Eleven questions in Google forms included all materials given in the six meetings, particularly about linguistics, the phonological term, 
pronunciation of certain words, the morphological formation and construction. The questions were chosen after considering materials which had been discussed in the classroom activities. The additional two questions given to Class B were syntactical tree diagram which they had practiced in classroom activities. The researcher used multiple choice, checkboxes, multiple choice grid, checkbox grid and short answer in the questions to see students' knowledge of the materials. The questions which only have one answer used multiple choice, while the questions that have more than one answer used checkboxes. Likewise, the researcher also used multiple choice grid and checkbox grid with the same reasons. Out of thirteen questions, only two questions required short answers in order to prevent typographical errors students often commit to do.

The students of STBA Pontianak who took Introduction to Linguistics subject in the Odd Semester 2019/2020 were 78 students, they were 47 students of the morning class (Class A), while 31 students of the afternoon class (Class B). The researcher involved all students to check their knowledge of materials, and to observe their understanding in using Google Forms. However, only 71 responds (41 students of Class A, and 30 students of Class B) recorded due to students' absence. From the responses, the study found different results of two classes in answering eleven questions.

The first question was about the definition of linguistics, the students should choose one of four available options. Out of 41 students in Class A, only 9 students (22\%) who answer it correctly, most of them (around 28 students or 68,3\%) misinterpreted the meaning of linguistics by choosing the definition of psychology. In the meantime, 15 students or $50 \%$ of Class B answered it correctly, while another $50 \%$ chose the incorrect answer.

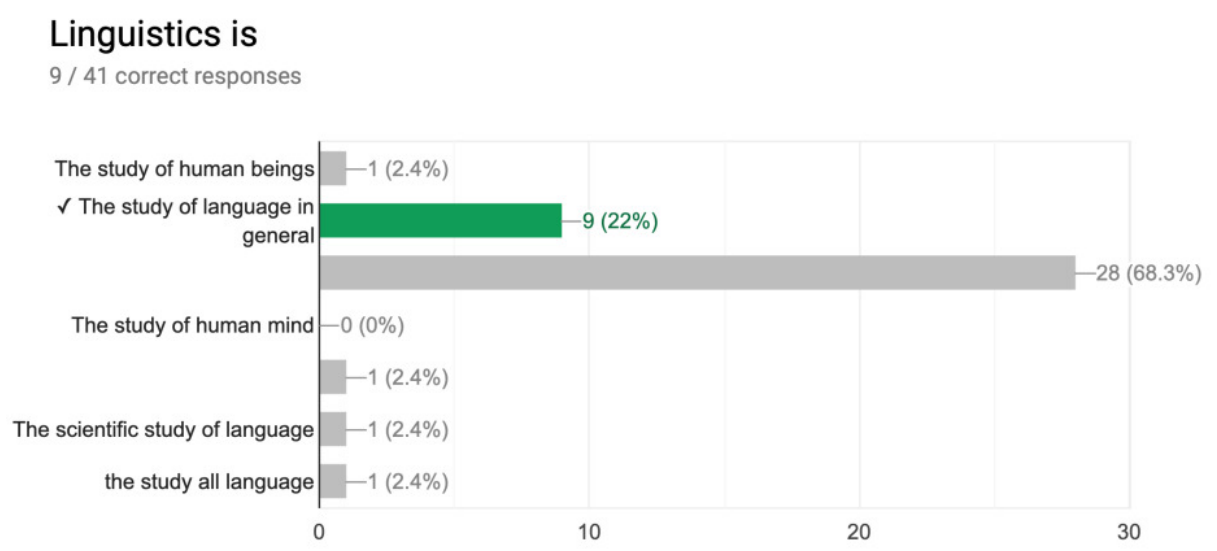

Figure 2 Chart of Response of The First Question in Class A 


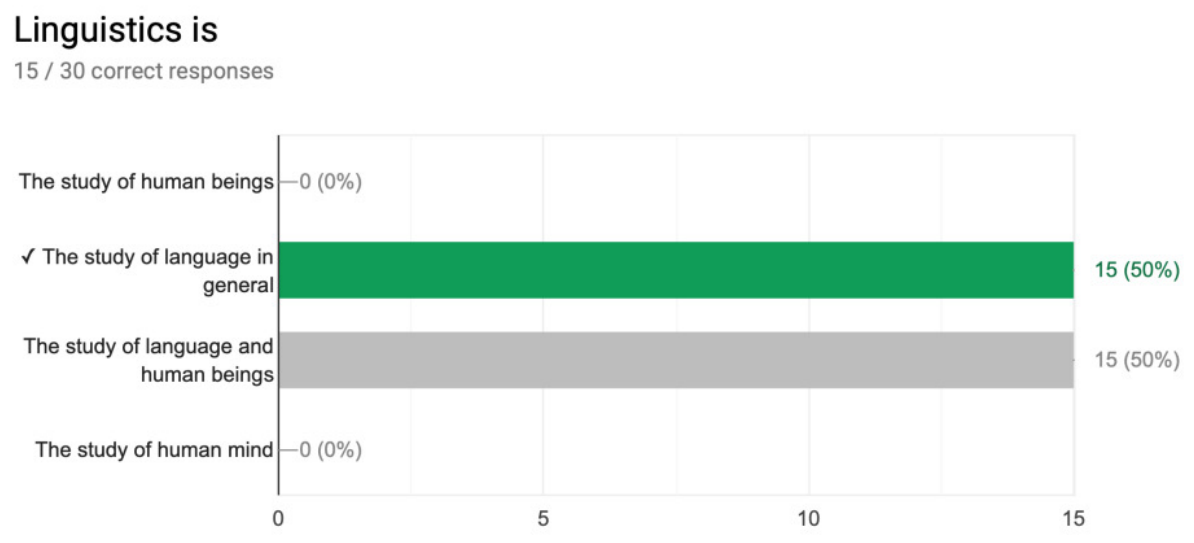

Figure 3 Chart of Response of The First Question in Class B

Through the second question, the researcher wanted to know students' understanding on the scope of linguistics. It found that there were $65.8 \%$ correct responds in Class A, while Class B only have $43.3 \%$ correct responds. In addition, the third question was still about the scope of linguistics. It seemed that students only knew about the term, but they did not know the categorisation of macro and micro linguistics. There were 27 out of 41 responds in Class A that correctly answered it; the figure was similar to the second question. In the meantime, there were $53,3 \%$ or 16 responds which correctly answered the third questions. Although the second and third question were actually related to each other, it seemed that students in Class B did not aware of it.

Furthermore, the researcher also asked about onomatopoeic words in the fourth question. Only 16 of 41 responds in Class A and 13 of 30 responds in Class B were correct. It means that less than $50 \%$ correct responds in both classes. The fifth question was about the abbreviation of IPA, the respondents were asked to write it in short answer. It has found that only $9.8 \%$ of Class A, and $30 \%$ of Class B wrote it correctly. The sixth question was about silent letters in six words (calf, edge, fascinate, logically, scissor and wednesday). The percentage of each word was different in Class A and Class B. For Class A, the highest percentage of correct answer was on the silent letter of 'logically', and the correct answers of all words only reached $68.3 \%$. Differently, Class B had different figures, $96.7 \%$ respondents answered the silent letter of 'wednesday', and $96.7 \%$ respondents also answered the correct silent letter of 'edge'. The seventh and eighth questions were about morphemes and affixes. In the seventh question, $87 \%$ of Class A, and $80.5 \%$ of Class B could differentiate free morphemes from bound morphemes. 
Determine the differences

37 / 41 correct responses

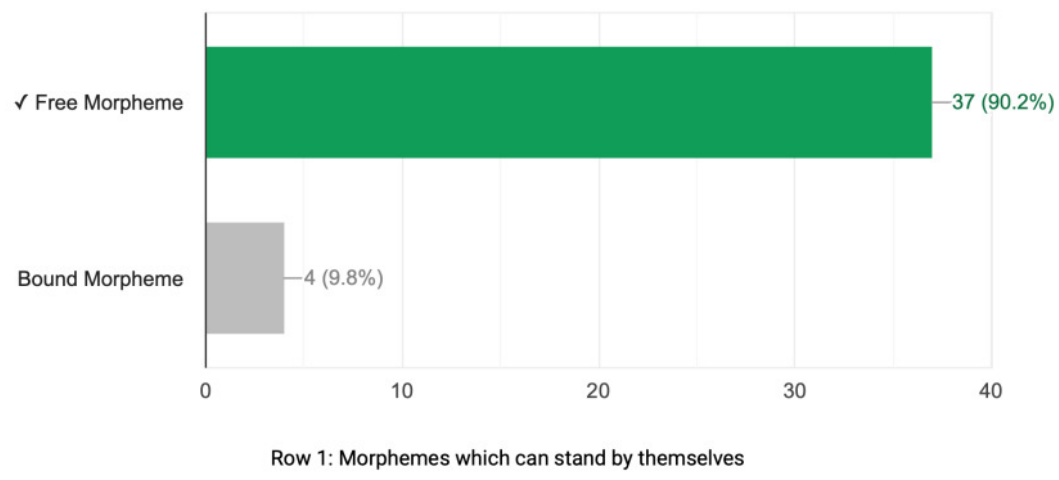

Figure 4 Chart of Response of The Seventh Question in Class A

\section{Determine the differences}

$28 / 30$ correct responses

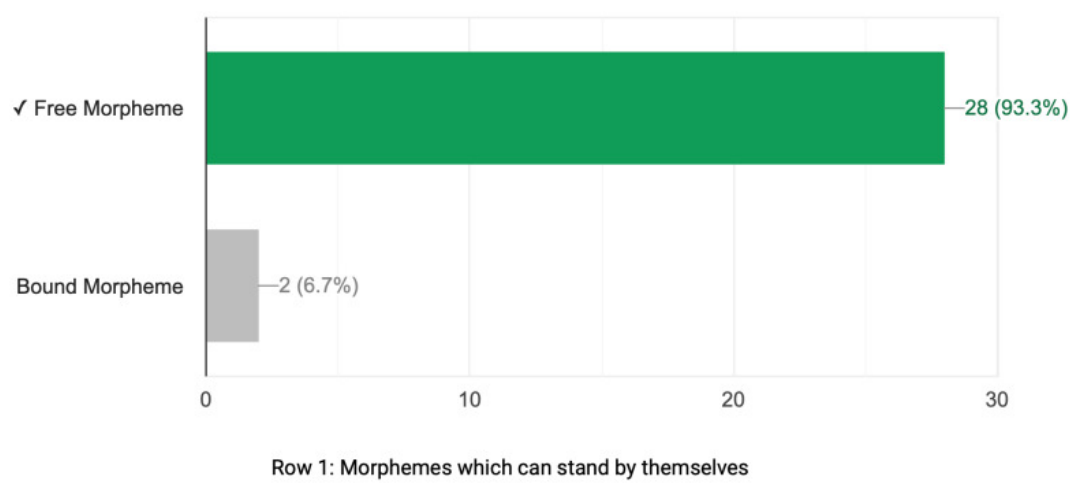

Figure 5 Chart of Response of The Seventh Question in Class b

In addition, the eight question was about prefix and suffix, there were $84.1 \%$ of respondents in Class A, and $94.1 \%$ of respondents in Class B answered it correctly. The respondents should also answer the ninth question about morphology, the question specifically asked the basis form formation of 'helpfulness'. Only 13 of 41 respondents answered it correctly in Class A, and 7 respondents in Class B. The respondents had to choose the correct diagram trees which formed the words 'disadvantageously' and 'undesirability' on the tenth and eleventh questions. Since images were also attached in the multiple choice, the respondents were only asked to pick one of four options. $46.3 \%$ of Class A, and $26.7 \%$ of Class B answered the tenth question correctly, while $58.5 \%$ of Class A, and $13.3 \%$ of Class B answered the eleventh question correctly.

The findings have shown that Class A and B have different results. Class B knew about linguistics better than Class A as more respondents of Class B answered the first to third questions correctly. Differently, the respondents from Class A were better in understanding free and bound morphemes than Class B; however, the former did not really understand affixes as good as the latter, it has found that the correct answers from Class A were only $84.15 \%$, while 94.15 of Class B answered it correctly. 
Table 1 The Results of Class A and Class B on The

\begin{tabular}{lll}
\hline Differences of Free and Bound Morphemes & Class A & Class B \\
\hline Row 1. Morphemes which can stand by themselves & $90.2 \%$ & $93.3 \%$ \\
Row 2. Morphemes which can't stand alone & $92.7 \%$ & $83.3 \%$ \\
Row.3 Morphemes which have meaning, although they stand alone & $95.1 \%$ & $80 \%$ \\
Row 4. Morphemes which need to be attached & $87.8 \%$ & $90 \%$ \\
Row 5. It is usually called root & $87.8 \%$ & $70 \%$ \\
Row 6. It consists of affixes & $68.3 \%$ & $66.7 \%$ \\
\hline
\end{tabular}

The basic understanding of morphemes did not support their analysis in morphological tree diagram. Comparing students' knowledge of Morphological tree diagram, the findings of both responses were also different. Only $46.3 \%$ of respondents of Class A knew about the formation of the word 'disadvantageously', while the respondents of Class B which correctly answered it were $26.7 \%$. Differently, there were $58.5 \%$ respondents of Class A, and only $13.3 \%$ respondents of Class B which knew the formation of the word 'undesirability'. For the morphological formation, another respondents chose the wrong option because they did not consider the basic formation of the word. Instead of using the dictionary to find the basic formation, they admitted that they only depended on their intuition in defining the word.

Google form is useful for the teacher or students. For the teacher, Google Form provides automatic calculation which enables feedback for the students to learn their mistakes. In other words, the teacher does not have to do manual calculation when she/he has set the scoring system. The teacher can download responses in .csv format, view responses in spreadsheets and download them, print all responses, and delete them all. By using Google forms, the students may also learn about their mistakes after receiving the announcement of their score in their e-mail.

Auto grading on Google forms only enables to calculate the correct answers as marked in the answer key feature. It would be suitable for grading multiple choice and multiple choice grid, it still needs manual grading in checkboxes, short answer, and checkbox grid. Google forms automatically calculate the point values set on each question; the key answer on multiple choice and multiple choice grid were only one option which enables the calculation of point value. Meanwhile, checkboxes and checkbox grid allow more than one answer which calculation only works if all correct boxes as marked in the answer key are checked, the calculation is also not working if any incorrect box was checked. In other words, if the test takers did not check all the correct boxes or incorrectly check the boxes, the score will not come up. In short answer, the written text should be similar to the answer key (particularly in term of capitalisation); otherwise, it is not calculated. 


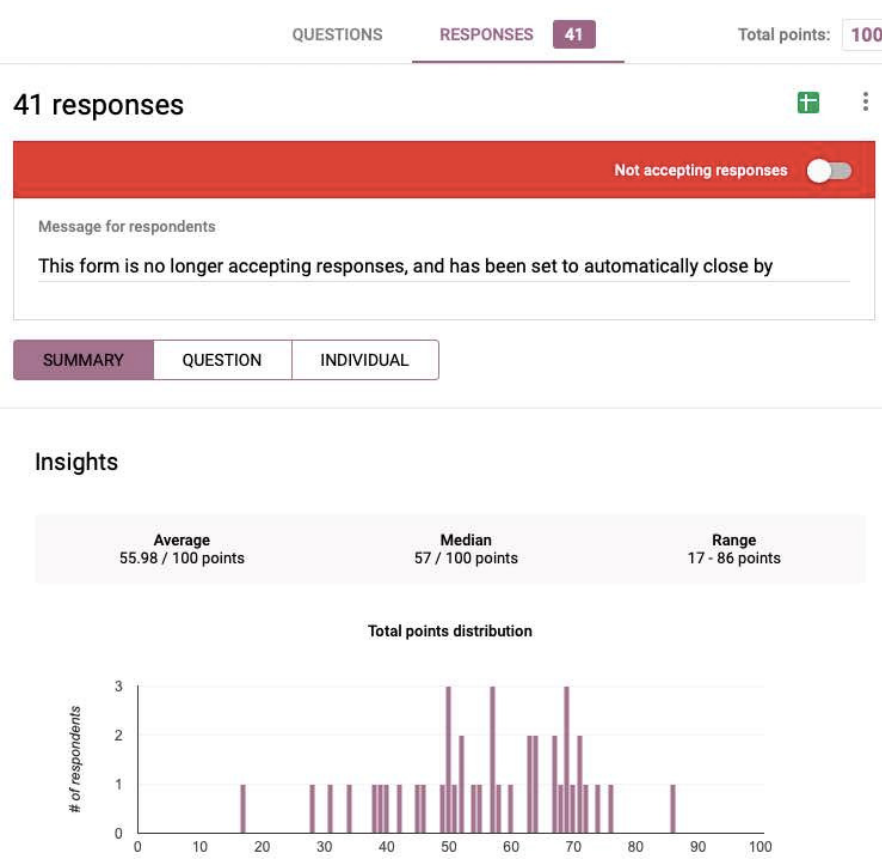

Figure 6 Insights of Scoring on Google Forms

In Google forms, manual grading is possible to do by looking at individual response one by one, checking the section score, and adding the score on each total points. Practically, the manual grading is still simpler than paper based assessment which still enables the intervention of subjective judgement, and requires the examiner to calculate and input the score repeatedly.

Nevertheless, the usage of Google forms in assessing students' knowledge was able to improve effectiveness and efficiency of teaching and learning process. To make sure that the assessment has impact on students' midterm performance, some of questions on midterm test were modified from the assessment question. The test was still paper based test, in which the questions include the definition, differences of macro and micro linguistics, basic formulation of certain words, and morphological tree diagrams. The score of assessment was taken from the average score of Google Forms, while the midterm test score was taken by using the formula:

$$
\text { Average }=\frac{\text { Sum of Scores }}{\text { Number of Respondents }}
$$

In calculating the average score of the midterm test, the respondents who involved in the assessment were counted. The following table is a comparison of students' score in Class A and Class B.

Table 2 Comparison of Average Score of Assessment and Midterm Test

\begin{tabular}{lll}
\hline Class & Assessment & Midterm Test \\
\hline Class A & 55.98 & 72.2 \\
Class B & 55.37 & 82 \\
\hline
\end{tabular}


It can be seen that students' score was improved significantly after the assessment. The students of Class A have improved their scores from 55.98 into 72.2, while the students of Class B improved significantly, from 55.37 into 82. In other words, the assessment using Google Forms has successfully improved students' academic performance, particularly midterm test score.

\section{CONCLUSION}

Understanding students' needs is the initial phase which a teacher should take before deciding certain teaching approach or technique. It requires the teacher to prepare the teaching and learning process in detail, yet it also simplifies the duty.

It is generally known that student-centred learning has been promoted since few years ago, yet traditional teaching practice which lecture method is still mushrooming. Considering the needs of Generation-Z students and technology-savvy environment, Google Forms, at least for another teacher in Sekolah Tinggi Bahasa Asing/STBA Pontianak, can be the first learning choice for teachers to integrate technology in classroom activities.

The study was merely conducted in the small-scale setting; thus, a further study on a largescale setting should be done. In addition, the future researcher should consider to assess the questions (particularly English skill) on online survey tools with Bloom's taxonomy in order to evaluate the level of students' mastery.

\section{REFERENCES}

Aalaei, S., Ahmadi, M. A. T., \& Aalaei, A. (2016). A Comparison of Multiple-Choice and Essay Questions in the Evaluation of Dental Students. International Journal of Advanced Biotechnology and Research, 7(5), 1674-1680.

Alkamel, M. A., \& Chouthaiwale, S. S. (2018). The Use of ICT Tools in English Language Teaching and Learning: A Literature Review. Journal of English Language and Literature (JOELL), 5(2), 29-33.

Castro, S. (2018). Google Forms Quizzes and Substitution, Augmentation, Modification, and Redefinition (SAMR) Model Integration. Issues and Trends in Educational Technology, 6(1), 4-14. Retrieved from https://www.learntechlib.org/p/188257/

Cilliers, E. J. (2017). The Challenge of Teaching Generation Z. PEOPLE: International Journal of Social Sciences, $3(1), \quad 188-198$. https://doi.org/10.20319/pijss.2017.31.188198

Cohen, S. S. (2016). How Teachers Conceive Their Role When Working with Generation Z Pupils in a Technological Learning Environment (University of Derbyw). Retrieved from http://creativecommons.org/licenses/by/4.0/LinktoItemhttp://hdl.handle.net/10545/62 0659

Creswell, J. W. (2014). Research Design: Qualitative, Quantitative and Mixed Method 
Approaches (4th ed.). London: SAGE Publication Ltd.

Devi, K. S., Gouthami, E., \& Lakshmi, V. V. (2019). Role of Social Media in Teaching Learning Process. Journal of Emerging Technologies and Innovative Research, 6(1), 96-103. Retrieved from https://www.researchgate.net/publication/330497773_Role_of_Social_Media_in_Tea ching-Learning_Process

Dunham, B., Yapa, G., \& Yu, E. (2015). Calibrating the difficulty of an assessment tool: The blooming of a statistics examination. Journal of Statistics Education, 23(3), 1-33. https://doi.org/10.1080/10691898.2015.11889745

Fernández-Cruz, F. J., \& Fernández-Díaz, M. J. (2016). Generation Z's Teachers and their Digital Skills. Comunicar, 24(46), 97-105. https://doi.org/10.3916/C46-2016-10

Guskey, T. R., \& Anderman, E. M. (2013). In Search of a Useful Definition of M(201astery. Educational Leadership, 71(4), 18-23.

Haddad, R. J., \& Kalaani, Y. (2014). Google forms: A Real-Time Formative Feedback Process for Adaptive Learning. 121st ASEE Annual Conference and Exposition, Conference Proceedings, (August 2006).

Handayani, F. (2016). Instagram as a Teaching Tool? Really? Proceedings of the Fourth International Seminar on English Language and Teaching (ISELT-4), 320-327.

Hidayati, T. (2016). Integrating ICT in English Language Teaching and Learning in Indonesia. JEELS, 3(1), 38-62.

Jabbarifar, T. (2009). the Importance of Classroom Assessment and Evaluation in Educational System. Proceedings of the 2nd International Conference of Teaching and Learning (ICTL 2009), 1-9. INTI University College, Malaysia THE.

Jones, V., Jo, J., \& Martin, P. (2007). Future Schools and How Technology can be used to support Millennial and Generation-Z Students. ICUT (Proceedings B), (January), 886-891. Retrieved from http://www98.griffith.edu.au/dspace/handle/10072/19022

Kato, T., \& Kambayashi, Y. (2016). Practice for Self-Regulatory Learning using Google Forms: Report and Perspectives. Information Englineering Express International Institute of Applied Informatics, 2(4), 11-20.

Kumara, B. T. G. S., Brahmana, A., \& Paik, I. (2019). Bloom's Taxonomy and Rules Based Question Analysis Approach for Measuring the Quality of Examination Papers. International Journal of Knowledge Engineering,5(1), 2-6. https://doi.org/10.18178/ijke.2019.5.1.111

Mohr, K. A. J., \& Mohr, E. S. (2017). Understanding Generation Z Students to Promote a Contemporary Learning Environment. Journal on Empowering Teaching Excellence, 1(1), 84-94. https://doi.org/10.15142/T3M05T

Purwati, T. (2019). Using Mobile Application To Promote Autonomous Learning for Syntax Subject. E-Structural, 1(02), 142-153. https://doi.org/10.33633/es.v1i2.2142 
Raju, N. V., \& Harinarayana, N. S. (2018). Online Survey Tools : A Case Study of Google Forms. National Conference on "Scientific, Computational \& Information Research Trends in Engineering, (December).

Salas-Morera, L., Arauzo-Azofra, A., \& García-Hernández, L. (2012). Analysis of Online Quizzes As a Teaching and Assessment Tool. Journal of Technology and Science Education, 2(1). https://doi.org/10.3926/jotse.30 